\title{
Towards the Parody Machine. Qualitative Analysis and Cognitive Processes in the Parody of a Politician
}

\author{
Isabella Poggi ${ }^{1}$ and Francesca D'Errico ${ }^{2}$ \\ ${ }^{1}$ Dipartimento di Filosofia, Comunicazione e Spettacolo - Università Roma Tre \\ isabella.poggi@uniroma3.it \\ ${ }^{2}$ Faculty of Psychology \\ Uninettuno International Telematic University (Utiu)- Rome \\ fderrico@uniroma3.it
}

\begin{abstract}
The paper presents a model of parody, viewed as a distorted imitation of a text, discourse, behavior or trait of a person performed in order to elicit laughter. Focusing on the parody of politicians as a way to discredit them for persuasive purposes, a qualitative analysis is presented of the parody of a Mayor of Rome by an Italian comedian. The role of allusion in parody, and its consequent dependency on culturally shared knowledge are highlighted, and the function of ridicule as a form of moralistic aggression is stressed. Finally a first flash of a procedure for the construction of a parody machine is provided, based on the cognitive process of parody in humans.
\end{abstract}

\section{From Computational Humor to the Parody Machine?}

Laughing at others is a formidable weapon against power; and a weapon of power. People make fun of others to abase them, to make them powerless and not to be afraid of them anymore. A way to do so is satire, and specifically to make a parody of someone: showing his flaws by making a caricature of his appearance or behavior.

The field of computational humor, has emerged in the last twenty years to build systems for the generation of humorous texts and images [1]. At the same time, multimodality and body signals have been so deeply studied as to lead to their simulation in Embodied Conversational Agents and Robots. Since humor is typically conveyed multimodally by the interaction of words and prosody with body movements, gestures, face, gaze, even suits or costumes, it should be possible now also to encompass multimodal bodily aspects within computational humor.

Parody is a such humorous behavior, in that it is often aimed at making people laugh about someone or something by funnily imitating it from semantic but also acoustic and visual points of view. So why not start thinking of a "parody machine"?

As for any case of simulation of a complex human activity, building a parody machine, one that given a person is able to extract her potentially ridicule flaws and to reproduce them in such a way as to make fun of them, might be motivated by at least two functions, a genuinely theoretical and an applicative one. The former is in the 
loop of modeling a human process, simulating it, getting a feedback through evaluation, and re-formulating the model accordingly: simulation as a way to test a conceptual model; and a model capable to account for the production of parodies must necessarily model subtle but important devices of social interaction. On the application side, beside the traditional functions of computational humor [2, 3], a "parody machine" might provide an automatic tool for finding out and displaying the ridiculous aspects of a character or object: a machine able to single out the weak points of a behavior or person might anticipate possible future reactions of others and in some cases induce to change course of action. A such machine might be an "alter-ego" warning us when the way we appear or behave may trigger laughter; a sincere friend who, when understanding we become ridicule, imitates us and lets us clumsiness emerge. But to build a parody machine requires an adequate model of parody: such first step is the objective of our work.

This paper defines the notion of ridicule (Sect. 2) in terms of a socio-cognitive model of communication and social interaction, then it overviews previous definitions (n.3) and presents its own notion of parody (n.4). Through a qualitative analysis of the parody of a mayor of Rome by an Italian comedian (n.5), it highlights the cognitive processes occurring in a Parodist' mind, and finally (n.6) provides some first flashes of a computational model of parody, figuring out what capabilities an Artificial System should be endowed with to automatically generate parodies.

\section{Ridicule: A Way to Discredit Others}

Ridiculization is a communicative act conveying a negative evaluation of someone, aimed at a sort of "moralistic aggression" [4] toward him/her, to be used as a sanction against a-social behaviour, possibly even with a pedagogical function. According to [5], a negative evaluation is the belief that some object, event or person does not have (or does not provide someone with) the power to achieve some goal. We evaluate something negatively either when it lacks the power to achieve some goal (negative evaluation from lack of power) or when it has the power of thwarting some goal (negative evaluation from noxiousness). When A ridicules $\mathrm{B}$, A conveys a negative evaluation of B for lack of power, but one that contrasts with some pretence of superiority exhibited by B. Such contrast between pretence of power and actual lack of power, whose outcome is though not threatening for A, can elicit laughter: the physiological expression of relief that follows the sudden disconfirmation of some expectation of danger, thus resulting in a sense of superiority. Ridiculization is then a communicative act through which a Sender S remarks, in front of some Audience A, a feature of a victim $\mathrm{V}$ evaluated as negative due to lack of power, contrasting with V's pretence of superiority, and seen as not threatening for $\mathrm{S}$ and $\mathrm{A}$, so as to elicit relief and laughter. Ridiculization further implies $\mathrm{S}$ deliberately soliciting Audience A to laugh at $\mathrm{V}$, with the goal of causing that:

a. S and A feel superior to $\mathrm{V}$, because they feel above the inadequacy of the victim, and not threatened by it; 
b. This common superiority strengthens the social bonds between $\mathrm{S}$ and $\mathrm{A}$, through the shared positive emotion of laughing together, through feeling similar to each other as opposed to different from V, and a sense of alliance and complicity;

c. With image and possibly self-image attacked, the Victim feels emotions of shame, humiliation, abasement, s/he feels different, rejected, isolated from the group. All this may induce V to future different behaviour: which is the function of ridiculization as "moralistic aggression" [4]: aggression from the group aimed at changing a member's conduct.

In previous works, [6] analyzed verbal and multimodal cases of ridiculization in political debates, where political opponents try to make fun of each other, to lower each other's credibility before voters, thus performing a "discrediting move", i.e., spoiling the other's image before an audience, for persuasive purposes. In persuasion, Persuader P aims at convincing an Audience A not only by what he says (logos), but also by the emotions he induces (pathos) and by the reliable image he presents of himself (ethos). Further, as well as $\mathrm{P}$ needs to project a positive image of himself, to prevent the Audience from being persuaded by an opponent $\mathrm{T}$, he may try to convey a negative image of him, i.e., cast discredit over T. In political persuasion, discredit is cast over opponents concerning three different features [8]: the politician's benevolence (caring the electors' goals, working on behalf of their interest, being trustworthy, honest, ethical), competence (expertise, skill, knowledge, planning and reasoning capacity), and dominance (capacity of winning in contests, of influencing others and imposing one's will). A politician may discredit the other on all three features through ridiculization, by signals in various modalities that call for the Audience's laughter: laughter or smile only or in combination with words; words only, withoutsmile or laughter; but also by irony and parody.

\section{$3 \quad$ Related Work on Parody}

What is parody? According to Holman and Harmon [8], parody is an imitation, intended to ridicule or criticize, that does not need a "pretense of ignorance" like in the socratic teacher, because familiarity with the original object is necessary: to be effective it has to "sound true" to the original [9].

A parody is not a simple imitation: first it has to be an "approximation" to an original source, since like in sarcasm "the subject is treated in a contradictory manner: elevated subjects are debased and "lowly" are elevated" [10].

The parodistic act presents a not so obvious nature from a linguistic and psychological point of view: Bachtin [11: 76] sees it as "an arena of conflict between two voices, they are detached but they are hostilely counterposed" and the second voice represents a "semantic authority". In his speculation on parody he specifies: "the audience knows for sure with whom it is expected to agree." The Parodist has a strong role of both communicating and informing the audience on a criticizable object or act. In fact Rossen-Knil and Henry [12] on the production side formally mention four 
pragmatic aspects of parody: (1) the intentional verbal representation of the object of parody, (2) the flaunting of the verbal representation, (3) the critical act, and (4) the comic act. On the comprehension side the parodistic act depends on the successful interaction between parodist and audience, since not only needs the latter recongnize the "authority" and the ethic or moralistic intention of the parodist, but it also needs to know vices and virtues of the character, if the parody is focused also on the body and verbal features (tic, stummer...) which are the innesco of the comic part.

A verbal parody involves a highly situated, intentional, and conventional speech act which re-presents the object of parody and flaunts that re-presentation in order to criticize that object in a humorous way [11].

\section{A Socio-cognitive Model of Parody}

In terms of our model, parody is a communicative act - a text or a verbal or multimodal communicative behaviour (discourse, song, film, fiction) - that performs a distorted imitation of another text or multimodal behaviour, with the aim of amusing and eliciting laughter. Not only a person, but also a text (a song, a novel, a drama) may be an object of parody.

In political satire, to make fun of the target $\mathrm{T}$ in front of the audience $\mathrm{A}$, the Parodist $\mathrm{P}$ imitates the Target's traits and/or communicative or non-communicative behavior, performing a distorted imitation that enhances the Target's flaws. To do so, the Parodist must 1. single out the most characterizing features of Target T's physical traits or behaviors, and 2. imitate them while exaggerating them in such a way as to make them appear ridicule.

How can a feature exhibited by $\mathrm{P}$ evoke a similar (but less extreme, less exaggerated) feature of $\mathrm{T}$ ? The key to parody is allusion. In Allusion, an Agent $\mathrm{P}$ wants an Addressee $\mathrm{A}$ to infer that $\mathrm{P}$ refers to $\mathrm{X}$, though not by explicitly mentioning $\mathrm{X}$ but simply making reference to it in an indirect way. $\mathrm{P}$ does not mention $\mathrm{X}$ out of reasons of euphemism or other kind of protection, and yet wants $\mathrm{A}$ to understand both what $\mathrm{P}$ refers to and why $\mathrm{P}$ does not mention it explicitly.

In imitation, $\mathrm{P}$ produces the trait or behavior $\mathrm{Y}$ while asking $\mathrm{A}$ to recognize it as similar to trait or behavior $\mathrm{X}$, so allusion in a sense is always present in any kind of imitation. But as I ask you to recognize $\mathrm{Y}$ as an imitation of $\mathrm{X}$, I presuppose that you know $\mathrm{X}$. Therefore imitation typically requires that the knowledge of $\mathrm{X}$ is shared by me and you: there must be a common culture, a shared frame of reference between the Imitator (the Parodist) and his Audience; so much so that both imitation and parody cannot be entirely understood across different cultures.

Due to its character of indirect, hence necessarily somewhat concealed type of communication, in both verbal and bodily allusion the referent cannot be mentioned in a clear and, so to speak, "central" way, but simply hinted at here and there during discourse or in the overall multimodal arrangement of the parodist. These hints, a sort of "key-words" that orient A to capture the allusion, concern the "allusion points": the contents in the background knowledge that are supposedly shared with A, and to which the Parodist wants to allude in his parody. 


\section{The Parody of a Politician. A Qualitative Analysis}

To better illustrate our definitions of parody and allusion, we present a qualitative analysis of a real parody of a politician: the Italian comedian Max Pajella's parody of Gianni Alemanno, a former exponent of the Italian fascist party Alleanza Nazionale (National Alliance), mayor of Rome since 2008 to 2013, one often criticized for having been a fascist drubber in his youth and, during his role as a Mayor, for his familism, since he hired lots of relatives and friends in the town bus company. Max Pajella is a skilled imitator and parodist working in the left-wing satire show "The show must go off", where he ridicule tics and behaviors of various right-wing politicians, appearing on the screen and talking to the show conductor, the comedian Serena Dandini, in the studio, while she comments on what he says and takes the role of his stooge. For his parody of Gianni Alemanno, Pajella picks up a recent episode in which the Mayor really made himself ridicule: the snow in Rome.

Below we describe the context and background of this event, with words in bold describing the "allusion points".

On February $3^{\text {rd }}, 2012$, a lot of snow came on Rome. Not so used to see snow, Rome is generally not well prepared to confront this challenge, but in this case, the disorganized management by Alemanno and his staff turned a meteorological event into a disaster. A newsletter from the national Civil Protection had warned him that $\mathbf{3 5}$ millimeters of water were expected; actually, 1 millimeter of water equates $1 \mathrm{~cm}$. snow, but Alemanno and his staff were not expert on this, so they expected 3,5 centimeters of snow instead of the 35 and more that came in fact. Probably due to this misunderstanding, no kind of prevention was undertaken: no salt to prevent streets from freezing, no snow chains for buses; buses stopped for hours with roman citizens inside, not to let them die for cold. Alemanno simply warned people to stay home, then he bought a stock of shovels and had them distributed to Roman citizens recommending to clean up their doors by themselves; he himself was videorecorded on TV while shoveling snow. Finally he often said he would call the army to cope with the emergency. When the emergency was over, Alemanno was accused of disorganization and inefficiency, and to justify himself he appeared in all possible TV news and talk shows imputing the disaster to the Civil Protection, who had not warned him how serious the situation was, and complaining that he had been left alone to confront the emergency.

Our hypothesis is that in a parody, each element of the parodist's imitation alludes to a relevant element of the story to cast ridicule on it; and analyzing a parody implies discovering the beliefs alluded to by each of the Parodist's words or visual behaviors, and the information, opinion, or evaluation they indirectly convey. In the following, we separately analyze Pajella's imitation of Alemanno's discourse and that of his multimodal behavior.

\subsection{Allusions and Parody in Alemanno's Costume and Background}

Pajella, acting Alemanno, shows on the screen with Coliseum in the background and flocks of snow gently falling down; he is dressed as a Roman centurion, his helmet 
on the ground, and holds a big shovel in his right hand and a sheet of paper in his left hand.

1. Coliseum with flocks of snow falling down alludes to snow in Rome: quite a "neutral" information, only aimed to set the stage of the parody.

2. Alemanno dressed as a Roman centurion alludes to the Roman tourist operators that welcome tourists around Coliseum dressed as centurions. This is not, though, a neutral information, but one loaded with somewhat negative evaluation: men playing centurions with tourists are generally connoted as underprivileged uneducated people from Roman slums, waiting for a tip after posing for a picture. This suit then conveys Alemanno a nuance of a lout, a buffoon.

3. The shovel in his hand alludes to (and ridicules) the shovels he distributed to Romans to help themselves, and to his showing himself shoveling, to project an image of a willing boy who, though left alone by civil protection, did everything he could to help. But one more inference can be drawn from this: Alemanno's impotence to manage emergency in Rome.

4. The sheet of paper in his left hand alludes to the newsletter from the Civil Protection about the centimeters of water expected: this points at Alemanno's ignorance in meteorology.

\subsection{Allusions and Ridicule in Alemanno's Words}

The same kind of analysis given in a discursive way on Pajella-Alemanno's costume and visual background is provided in a schematic way for his words in Table 1. In columns 1. and 2. we write the Parodist's words and their literal meaning, respectively; in col. 3 the belief each word or sentence alludes to, in 4 the indirect meaning conveyed by the allusion, and in 5 we finally classify the example in terms of the feature of the Target made fun of, whether Competence, Benevolence or Dominance. (Table 1)

Table 1. Pajella's words and their allusions

\begin{tabular}{|c|c|c|c|c|}
\hline 1.BELIEF MENTIONED & $\begin{array}{l}\text { 2.MEANING } \\
\text { DIRECTLY CONVEYED }\end{array}$ & $\begin{array}{l}\text { 3.BELIEF ALLUDED } \\
\text { TO }\end{array}$ & $\begin{array}{c}\text { 4.MEANING } \\
\text { TO BE INFERRED }\end{array}$ & $\begin{array}{c}\text { 5.RIDICULED } \\
\text { FEATURE } \\
\end{array}$ \\
\hline $\begin{array}{l}\text { Io sono stato lasciato } \\
\text { solo in questo Colos- } \\
\text { seo a spalare la neve } \\
\text { io sono stato lasciato } \\
\text { solo. }\end{array}$ & $\begin{array}{l}\text { I have been left alone; } \\
\text { in this Coliseum I have } \\
\text { been left alone shove- } \\
\text { ling snow. }\end{array}$ & $\begin{array}{l}\text { Alemanno often } \\
\text { complained he had } \\
\text { been left alone }\end{array}$ & $\begin{array}{l}\text { Alemanno plays } \\
\text { the victim to } \\
\text { justify himself: }\end{array}$ & $\begin{array}{l}\text { DOMINANC } \\
\text { E }\end{array}$ \\
\hline $\begin{array}{l}\text { Io se continua cosi } \\
\text { chiamo l'esercito. } \\
\text { La Protezione Civile } \\
\text { mi ha lasciato solo. }\end{array}$ & $\begin{array}{l}\text { If things go on like } \\
\text { this, I'll call the army. } \\
\text { Civil Protection has } \\
\text { left me alone }\end{array}$ & $\begin{array}{l}\text { A. always threat- } \\
\text { ened to call the } \\
\text { army: }\end{array}$ & $\begin{array}{l}\text { He threats but } \\
\text { also plays the } \\
\text { helpless }\end{array}$ & $\begin{array}{l}\text { DOMINANC } \\
\text { E }\end{array}$ \\
\hline $\begin{array}{l}\text { Dovevano dircelo che } \\
\text { l'acqua ghiacciava a } \\
\text { zero centigradi centi- } \\
\text { metri }\end{array}$ & $\begin{array}{l}\text { They should have told } \\
\text { us that water froze at } \\
\text { zero centigrade centi- } \\
\text { meters }\end{array}$ & $\begin{array}{l}\text { A.and his staff } \\
\text { proved very igno- } \\
\text { rant about meteoro- } \\
\text { logical facts }\end{array}$ & $\begin{array}{l}\text { A. is very igno- } \\
\text { rant }\end{array}$ & $\begin{array}{l}\text { COMPETEN } \\
\text { CE }\end{array}$ \\
\hline
\end{tabular}


Table 1. (Continued)

\begin{tabular}{|c|c|c|c|c|}
\hline $\begin{array}{l}\text { Perché la Protezione } \\
\text { civile aveva detto che } \\
\text { sul Campidoglio sa- } \\
\text { rebbero piovuti soltan- } \\
\text { to } 35 \text { millimetri di } \\
\text { mmerda. }\end{array}$ & $\begin{array}{l}\text { Because Civil Protec- } \\
\text { tion had said that only } \\
35 \text { millimeters shit } \\
\text { would have fallen on } \\
\text { Capitolium. }\end{array}$ & $\begin{array}{l}\text { The snow was } \\
\text { cause of a great loss } \\
\text { of face for } \mathrm{A} \text {. }\end{array}$ & & $\begin{array}{l}\text { DOMINANC } \\
\text { E }\end{array}$ \\
\hline $\begin{array}{l}\text { a tutti coloro } i \text { quali, } \\
\text { quei romani i quali } \\
\text { sono rimasti dentro } \\
\text { bloccati sugli autobus, } \\
\text { i cinquantotti barrati, } \\
\text { i sessanta notturni, }\end{array}$ & $\begin{array}{l}\text { to all those who, those } \\
\text { romans who remained } \\
\text { blocked on the bus, } \\
\text { barred fiftyeights, the } \\
\text { night sixties, }\end{array}$ & $\begin{array}{l}\text { Cinquantotti (the } \\
\text { plural of a number) } \\
\text { alludes to A.'s lin- } \\
\text { guistic ignorance }\end{array}$ & $\begin{array}{l}\mathrm{He} \text { is ignorant } \\
\text { also in Italian } \\
\text { language }\end{array}$ & $\begin{array}{l}\text { COMPETEN } \\
\text { CE }\end{array}$ \\
\hline $\begin{array}{l}\text { A: vi sono vicino, è } \\
\text { come se foste tutti } \\
\text { quanti parenti miei. } \\
\text { D: Come se fossero } \\
\text { parenti suoi?? In } \\
\text { realtà, molti lo sono... } \\
\text { vabbè, lasciamo per- } \\
\text { dere }\end{array}$ & $\begin{array}{l}\text { A.:I am close to you, } \\
\text { as if you all were rela- } \\
\text { tives of mine. } \\
\text { D: As if they were } \\
\text { your relatives?? Ac- } \\
\text { tually, many are.... } \\
\text { Ok, just let it go... }\end{array}$ & $\begin{array}{l}\text { This alludes to A.'s } \\
\text { familism in hiring } \\
\text { all his relatives in } \\
\text { the bus company. }\end{array}$ & $\begin{array}{l}\mathrm{He} \text { is dishonest } \\
\text { because he is } \\
\text { familistic in his } \\
\text { administration }\end{array}$ & $\begin{array}{l}\text { BENEVOLE } \\
\text { NCE }\end{array}$ \\
\hline $\begin{array}{l}\text { D: Eh, non sarebbe it } \\
\text { caso di tendere un po } \\
\text { più la mano alla Pro- } \\
\text { tezione Civile? Colla- } \\
\text { boriamo bene, mo? }\end{array}$ & $\begin{array}{l}\text { D: Well, shouldn't you } \\
\text { lend a hand to Civil } \\
\text { Protection more? Are } \\
\text { we collaborating well, } \\
\text { now? }\end{array}$ & $\begin{array}{l}\text { People commented } \\
\text { that the Mayor and } \\
\text { the Civil Protection } \\
\text { should have colla- } \\
\text { borated more }\end{array}$ & $\begin{array}{l}\text { A. did not colla- } \\
\text { borate but only } \\
\text { cast discredit on } \\
\text { the Civil Protec- } \\
\text { tion }\end{array}$ & $\begin{array}{l}\text { BENEVOLE } \\
\text { NCE }\end{array}$ \\
\hline $\begin{array}{l}\text { A: Su questo le posso } \\
\text { dire che ha raggione: } \\
\grave{e} \text { il momento di ten- } \\
\text { dergli una mano ... e } \\
\text { prenderli a ccatenate! } \\
\text { Se solo si trovassero } \\
\text { ste catene.... Però, 'n } \\
\text { se trovano! }\end{array}$ & $\begin{array}{l}\text { A: About this I can tell } \\
\text { you that you're right: } \\
\text { it's time to lend them a } \\
\text { hand.... And take } \\
\text { them by chain hits! If } \\
\text { only we might find } \\
\text { these chains... But } \\
\text { you can't find them! }\end{array}$ & $\begin{array}{l}\text { Alemanno as a } \\
\text { fascist drubber in } \\
\text { his youth, possibly } \\
\text { using chains to hit } \\
\text { political rivals } \\
\text { Snowchains lacking } \\
\text { in the emergency }\end{array}$ & $\begin{array}{l}\text { A.was disorga- } \\
\text { nized }\end{array}$ & $\begin{array}{l}\text { BENEVOLE } \\
\text { NCE }\end{array}$ \\
\hline
\end{tabular}

\subsection{Allusion, Parody, and Culture}

The annotation of Table 1 allows us to assess density and quality of the parody itself, measured, respectively, in terms of the number of ridiculing allusions, and of how much the Victim is made fun of concerning his immorality, incompetence, or impotence. But Table 1 shows as well how parody cannot exist without allusion, because it relies on the imitation of traits or behaviors of the Victim; the similarity between the trait exhibited or the behavior performed by the Parodist and the corresponding trait 
or behavior of the victim cannot be caught unless the Addressee is acquainted with the Victim's behaviors and traits. The Audience cannot understand who the Parodist is imitating and alluding to if it does not share the Parodist's culture, i.e. the same knowledge and values.

\section{Toward the Parody Machine?}

How could we build a Parody Machine? The cognitive process necessary for a Human to perform a parody - that we should simulate to make an Embodied Agent able to perform parodies - implies at least the following requirements:

1. having a goal of moralistic aggression toward a Victim, to be pursued through ridicule.

2. having "sense of humor", i.e., the capacity for grasping scenarios feasible to being the object of fun or laughter, while distinguishing them from those that cannot or should not.

3. singling out one or more traits or behaviors of the Victim that are worth being ridiculed.

4. having (and searching) one's Model of the Addressee: a representation of what knowledge about the Victim is shared, and whether it may be subject to negative evaluation by the Addressee too.

5. imitating the traits, body behavior, or verbal text or discourse singled out as potentially ridicule, by exaggerating them, and possibly accompanying them with signals of allusion to induce the Audience to search its memory for similar traits or behaviors in the Victim and attach a tag of ridicule to it.

In the same vein, an Artificial System capable of performing parodies should be endowed with:

a. a capacity for having goals of moralistic aggression;

b. "sense of humor", i.e., capacity for grasping traits and behaviors feasible to being made fun of;

c. a cultural database on the behaviors and traits of possible Victims of parody;

d. a User Model of the Audience, to set which cultural beliefs and values concerning the Victim are shared and which are not

e. a body signals detection module to capture the recurrent physical features that characterize the style of the Victim's body behavior

f. an Imitation module, i.e., the capacity to display the same traits or behaviors as the Victim imposing the same physical features to one's imitative body behavior

g. an exaggeration module, i.e., the capacity to imitate the Victim's features by exaggerating them, but up to a realistic threshold, not in such a way as to make them unrecognizable by an Audience.

A simplified scheme of the process leading from perception of ridicule features to their distorted imitation is represented in Fig. 1.

Future research should implement the various steps of this procedure to build a Parody Machine. 


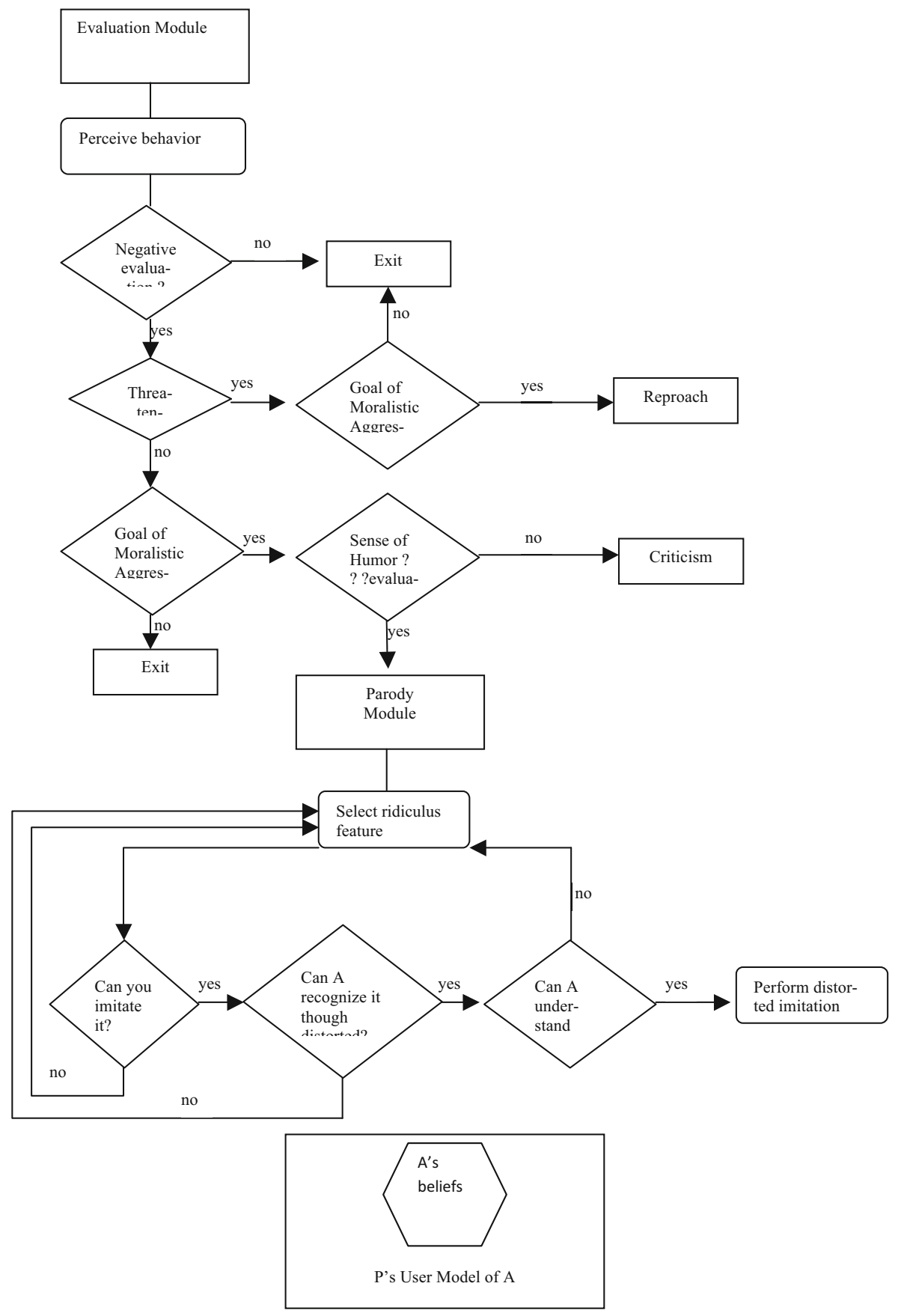

Fig. 1. The Parody process 
Acknowledgements. Research supported by SSPNet Seventh Framework Program, European Network of Excellence SSPNet (Social Signal Processing Network), Grant Agreement N.231287.

\section{References}

1. Hulstijn, J., Nijholt, A. (eds.): Proceedings of the International Workshop on Computational Humour (TWLT 12). University of Twente, Enschede (1996)

2. Morkes, J., Kernal, H., Nass, C.: Effects of humor in task-oriented human-computer interaction and computer-mediated communication. Human-Computer Interaction 14, 395-453 (1999)

3. Stock, O., Strapparava, C.: HAHAcronym: A Computational Humor System. In: Proceedings of the ACL Interactive Poster and Demonstration Sessions, pp. 113-116. Association for Computational Linguistics, Ann Arbor (2005)

4. Bischof, N.: On the phylogeny of Human Morality. In: Stent, G.S. (ed.) Morality as a Biological Phenomenon. The Presuppositions of Sociobiological Research. University of California Press, Berkeley (1980)

5. Miceli, M., Castelfranchi, C.: The role of evaluation in cognition and social interaction. In: Dautenhahn, K. (ed.) Human Cognition and Agent Technology. John Benjamins, Amsterdam (1998)

6. Poggi, I., D'Errico, F., Vincze, L.: Ridiculization in public debates: making fun of the other as a discrediting move. In: Calzolari, N., et al. (eds.) Proceedings of the 8th Conference on International Language Resources and Evaluation (LREC 2012), Istanbul, May 21-27, pp. 44-50. European Language Resources Association, ELRA (2012)

7. D’Errico, F., Poggi, I., Vincze, L.: Discrediting signals. A model of social evaluation to study discrediting moves in political debates. Special issue in "Social signal processing". Journal on Multimodal User Interfaces 6(3-4), 163-178 (2012)

8. Holman, C.H., Harmor, W.: The handbook to literature, 5th edn. Macmillan, New York (1986)

9. Falk, R.P.: American literature in parody: a collection of parody, satire and literary burlesque of American writers past and present. Twayne, New York (1995)

10. Kreuz, R.J., Roberts, R.: On satire and parody: The importance of being ironic. Metaphor and Symbolic Activity 8(2), 97-109 (1993)

11. Bakhtin, M.M.: From the prehistory of novelistic discourse. In: Holquist, M. (ed.) The Dialogic Imagination, pp. 41-83. University of Texas, Austin (1981); Emerson, C., Holquist, M. (Trans.)

12. Rossen-Knill, D.F., Henry, R.: The pragmatics of verbal parody. Journal of Pragmatics 27(6), 719-752 (1997)

13. Attardo, S., Eisterhold, J., Hay, J., Poggi, I.: Multimodal Markers of Sarcasm and Irony. Humor 16(2), 243-260 (2003)

14. Ruch, W. (ed.): The Sense of Humor: Explorations of a Personality Characteristic. Mouton-de Gruyter, The Hague-Berlin (1998) 